\title{
Postcolonial Political Institutions in the South Pacific Islands: A Survey
}

\author{
Jon Fraenkel
}

\section{Jon Fraenkel: Personal Journey}

I arrived at the University of the South Pacific (USP) in December 1995, straight out of the English winter into Fijis baking summer, and completed a PhD thesis on the British economy while being chewed by mosquitoes on the balcony at Knolly Street. After several years as a joint appointee of the economics and history/politics departments, I helped set up the new Pacific Institute of Advanced Studies in Governance and Development (PIAS-DG). Teaching mature professional students from around the Pacific Islands in the master's program of PIAS-DG was one of the most interesting and rewarding teaching jobs I've ever had. I'm still in contact with many of those students. I moved to The Australian National University in March 2007, just after the military coup, but retain many links and friendships with those at USP. In 2012, I moved again to Victoria University of Wellington, another regional university with close links to USP. Visiting Fiji in January 2019, I took my 13-year-old son onto the USP Laucala campus. Upon seeing the elegant vavai (rain trees), sekoula (flame trees) and towering royal palms he said, 'Dad, this is way cooler than your other workplaces'.

Fraenkel, J. 2013. Post-Colonial Political Institutions in the South Pacific Islands: A Survey. In D. Hegarty and D. Tryon (eds), Politics, Development and Security in Oceania. Canberra: ANU Press, 29-49.

Republished with the kind permission of ANU Press. 


\section{Vue d'ensemble des Institutions politiques postcoloniales dans le Pacifique Sud insulaire}

A partir du milieu des années 80 et jusqu'à la fin des années 90, les nouveaux pays du Pacifique sortaient d'une période postcoloniale marquée au début par l'optimisme et dominée par une génération de dirigeants nationaux à la tête d'un régime autoritaire pour connaître par la suite une période marquée par les difficultés et l'instabilité et qui a connu le coup d'Etat de Fidji de 1987, la guerre civile à Bougainville, le conflit néocalédonien et l'instabilité gouvernementale au Vanuatu et ailleurs. Dans les pays de la Mélanésie occidentale, cette instabilité a été exacerbée par des pressions exercées par des sociétés minières et des sociétés forestières étrangères. Cette étude retrace l'évolution et explore les complexités des diverses institutions politiques postcoloniales dans le Pacifique Sud à la fois au sein de ces institutions et dans leurs relations entre elles ; elle montre que les questions de science politique classique ont été abordées de façons extrêmement différentes dans la région. On y trouve une gamme de systèmes électoraux comprenant à la fois des régimes présidentiels et des régimes parlementaires ainsi que des situations de forte intégration d'un certain nombre de territoires au sein de puissances métropolitaines. Entre les deux extrêmes de l'indépendance totale et de l'intégration, les îles du Pacifique sont le lieu où l'on trouve un éventail d'arrangements politiques hybrides entre les territoires insulaires et les anciennes puissances coloniales. Cet article examine l'absence de partis politiques disposant d'une base populaire dans le Pacifique, les faibles taux de représentation des femmes et l'expérience acquise par le Pacifique en matière d'accords de partage du pouvoir ; il pose également la question de savoir si la fin de la période de l'état de grâce qui a suivi l'indépendance représente un glissement vers une instabilité permanente ou simplement un intermède précédant une certaine consolidation du pouvoir.

After decolonisation, the new Pacific nations mostly experienced a brief honeymoon period, presided over by a generation of relatively strong national leaders: Fiji's Ratu Sir Kamisese Mara, Papua New Guinea's Michael Somare, Vanuatu's Walter Lini, Amata Kabua in Marshall Islands, Ieremai Tabai in Kiribati, and Nauru's Hammer de Roburt. The late 1980s and 1990s saw the demise of that initial postcolonial optimism. Fiji witnessed its first coup in 1987, and a year later the Bougainville civil war began in earnest. New Caledonia erupted into conflict in the mid-1980s until tensions were calmed by the 1988 Matignon and then 1998 Noumea Accords. Vanuatu's bipolar party system began to fracture in the late 1980s, and intense government instability reigned across the 1990s. For later decolonisers, like Tuvalu, the watershed was also later; 
the two elections of 1993 proved the catalyst for an end to the early era of stability, after which the fall of governments became more frequent (Panapa and Fraenkel 2008). In the Marshall Islands, it was the death of Amata Kabua in 1996 that ended a hitherto unipolar style of government with no genuine opposition, and precipitated the opening of a period of sharper rivalry between the deceased president's successor, Imata Kabua, and the opposition United Democratic Party (UDP) led by a commoner, Kessai Note.

In the western Melanesian countries, heightened instability during the 1990s was encouraged by increasing interest from foreign companies in the natural resource extractive sectors. The Solomon Islands Government remained reasonably stable until Solomon Mamaloni's second government, when most ministers acquired strong links with logging companies (Frazer 1997:41). The political links of mining and forestry companies became increasingly important in PNG politics, particularly around election time. Growing popular discontent with parliamentary processes was indicated by high turnover rates among elected members of parliament (MPs). Issues of corruption became a focal point for the assembly of loose opposition coalitions; the reformist governments that took power in the Solomon Islands under Francis Billy Hilly in 1993 and under Bartholomew Ulufa'alu in 1997 both tried to define themselves through opposition to the 'Mamaloni men' (a reference to backers of the governments of Solomon Mamaloni, 1981-84, 1989-93, 1994-97, which were closely associated with Asian logging companies). Even in Tonga, where the monarchy remained in control, in the 1990s, 'Akilisi Pohiva and the other pro-democracy activists turned from agitation against abuses of office to radical demands for a shift away from royal control over government. Only Samoa remained reasonably stable, as the Human Rights Protection Party (HRPP) saw off challenges from the Tümua and Pule movement in 1994 and consolidated its grip on state power.

The Pacific Islands region includes entities closely incorporated with the metropolitan powers located around the Pacific Rim, such as Guam (US), Rapa Nui (Chile) and Tokelau (New Zealand), as well as independent states like Papua New Guinea, Fiji and Kiribati. The region includes countries that achieved independence less than 30 years ago, as well as those that are still in the process of adjustment to the postcolonial order. It includes resource-rich territories with strong potential for integration into the world economy alongside chronically resource-poor countries with limited avenues for export-driven economic growth. It includes 
territories with open access to metropolitan labour markets, and countries without. It includes an extraordinary ethnolinguistic diversity, mostly in Melanesia, which alone accounts for one fifth of the world's documented living languages. ${ }^{1}$ It includes relatively big nations like Papua New Guinea (6.6 million) alongside tiny micro-states like Niue, which has a population of only 1,500, and minute dependent territories like Pitcairn Island with only 45 inhabitants. Of the 9.7 million people that inhabit the 551.5 thousand square kilometre land area of Oceania, just over twothirds are in Papua New Guinea.

Classical political science questions have been addressed in strikingly different ways across the region-whether to accommodate ethnic diversity through unitary, devolved or federal systems; whether to handle conflict through majoritarian or proportional electoral systems and/or through power-sharing arrangements and whether to adopt parliamentary or presidential systems; or, as in Kiribati and in the autonomous region of Bougainville, some hybrid between the two. Other important questions for the region have been how to meld traditional forms of governance with imported institutions; how to respond to exceptionally low levels of women's representation; and how to build states in countries where-for many who live in rural areas and engage largely in subsistence cultivationthe state matters little.

\section{Electoral Systems}

Oceania has a history of electoral experimentation. Enthusiasm for preferential voting in the Pacific has been encouraged by Australia's adoption of the alternative vote (AV) for the federal parliament in 1918. Colonially inherited first-past-the-post systems have been ditched in favour of single-member preferential systems in Fiji and Papua New Guinea, although in both cases without the expected results (Fraenkel and Grofman 2006; May 2008). In Fiji, the alleged 'unfairness' of outcomes under the AV system was used to justify coups both in 2000 and 2006. When it was adopted in the mid-1990s, AV was intended to boost the chances of the moderate centrists, and to disadvantage ethnic extremists. Instead, it triggered a sharpening of electoral polarisation.

1 Based on data from the US Summer Institute of Linguistics, www.ethnologue.com/ethno_docs/ distribution.asp?by=area. 
Nauru has a unique simultaneously tallied preferential voting system, which oddly resembles the arrangements invented by 19th-century French mathematician Jean-Charles de Borda (Reilly 2001). Kiribati uses a two-round system similar to that in mainland France, although unusually in multi-member constituencies. That system permits voters to express preferences, although over two rounds rather than in a single round of $\mathrm{AV}$ voting. ${ }^{2}$ It is also considerably simpler to administer and count than the AV system, even if the need for two elections inevitably raises administrative costs.

List proportional representation (PR) systems are used only in the French territories. Unlike majoritarian systems, list PR systems aim to make the share of seats won by each party roughly equivalent to its share of votes, although there is a 5 per cent threshold below which parties gain no seats at all. By definition, list PR requires multi-member constituencies. New Caledonia, for example, is divided into three constituencies, the south (with 32 seats), the north (with 15) and the Loyalty Islands (with seven) for elections to the 54 member territorial congress. Voters simply tick the ballot paper next to their favoured political party and the parties submit lists of their candidates in order of preference. After the votes are tallied, electoral officials calculate which members are elected according to each party's share of the vote. In 2004, President Gaston Flosse modified French Polynesia's list PR voting system so as to give a 30 per cent seat bonus to the winning party, thus deliberately removing the system's proportionality. His aim was to give his Tahoeraa Huiraatira Party a stable working majority and to end many years of dependence on coalition government. The result was a crashing defeat for Tahoeraa Huiraatira, and the election instead of pro-independence leader Oscar Temaru. Instead of opening an era of stability, French Polynesia entered a politically chaotic period, with the presidency switching back and forth between the various factions. Paris stepped in to squash Flosse's failed reform in 2007.

Vanuatu is one of the few countries in the world to still use the single non-transferable vote (SNTV) system, alongside Jordan and Afghanistan. In an effort to bind francophone secessionists into the emerging Vanuatu state, British and French colonial authorities agreed on SNTV in the hope of avoiding a clean sweep for Walter Lini's anglophone Vanua'aku Pati (VP). Under SNTV, voters have a single vote, but constituencies have multiple members. Thus, if there is a 40 per cent francophone minority

$2 \mathrm{AV}$ is often called 'instant runoff voting' in the US due to this characteristic. 
in a three-seat constituency, and if francophones avoid splitting their votes, they should be able to pick up at least one of the three seats. The system achieved its objective reasonably well in the initial elections after independence, when the parties were reasonably disciplined and the contest was a bipolar one between the VP and the francophone Union of Moderate Parties. From the late 1980s, however, the francophone/ anglophone cleavage faded in significance, and parties splintered (Van Trease 2005). As political parties multiplied, SNTV became less predictable, victor's majorities reduced in size, and an increasing number of independent candidates contested.

Principles of universal suffrage and voter equality have, in some parts of the Pacific, sat awkwardly alongside traditional systems of authority. In Tonga, the king has not been-as often characterised-an absolutist monarch. Tonga's kings have been bound by the 1875 Constitution. It is the weak powers of parliament that have set Tonga apart from its neighbours. The prime minister and cabinet have been selected directly by the king, and sat in the legislature alongside nine nobles and nine people's representatives. Although there has been universal adult suffrage, there has been no effort to achieve voter equality: the holders of 33 noble titles selected nine noble representatives, while the rest of Tonga's 100,000 people chose nine people's representatives. Commitment to change has been in the air since 2005, oddly preceding the riots that destroyed much of Nuku'alofa in late 2006. In 2005, for the first time one of the people's representatives, Dr Feleti Sevele, became prime minister. The king subsequently declined to over-rule Dr Sevele's choice of cabinet ministers.

Upon his coronation in 2008, the new king, George Tupou V, committed to a majority popularly elected parliament. Parliament settled upon a first-past-the-post system and elections to the country's first-ever majority popularly elected assembly took place in November 2010. Under the new arrangements, the nine nobles' seats remain, but now together with 17 elected 'people's representatives'. Contrary to expectations that pro-democracy campaigner 'Akilisi Pohiva would assume control, his party gained only 12 of the 17 popularly elected seats. The remaining five independents aligned themselves with the nine nobles to select Noble Tuivakano as prime minister. Although no longer responsible to the king, Tonga retains its tradition of strong centralised government: the prime minister is entitled to nominate an additional four members of parliament, and cannot be ousted by a 'no confidence' vote for 18 months after an election. 
The principle of universal suffrage was not accepted by the architects of Samoa's 1962 constitution. Initially, both voters and candidates had to be holders of matai titles (a term often misleadingly translated as 'chief', but possibly better translated as 'family head'). A visiting United Nations team in 1959 argued that since there was an internal family decisionmaking process prior to the awarding of matai titles, the Samoan system could be regarded as one of 'election at two stages' (So'o and Fraenkel 2005:335). During the 1980s, that system was widely perceived—within Samoa - to have led to a proliferation of matai titles, triggered by rival parties exploiting the constitution's incentives to expand their voter bases by awarding titles. In 1990, there were 21,649 such titles, almost double the level a decade earlier. In that same year, the country voted to shift to a universal suffrage, although retaining the matai-only qualification for candidates. The change had several important repercussions for Samoan politics, but it did not halt the multiplication in the number of matai titles. In 1999, over 35,000 matai titles were on the books of the Land and Titles Court (So'o and Fraenkel 2005:342).

\section{Presidential or Parliamentary Systems}

The Pacific's presidential systems are mostly in the north where the US influence exerts greatest sway. Freely associated Palau most closely resembles the US model, with a president and congress and even a miniature replica of Washington's Capitol Building. The Commonwealth of the Northern Marianas, Guam and American Samoa have governors, rather than presidents, but are faithful to the American model of having direct popular elections for the head of government. The Marshall Islands and Nauru depart from the pattern in having 'presidents' that are more like prime ministers in the Westminster system; they are elected by parliaments. Kiribati is a unique hybrid since, although it has a directly elected president, (i) the nominees for the presidential election are selected through a complex parliamentary ballot, (ii) the president must form his cabinet from within parliament, and (iii) the president, despite being directly elected, can be ousted by a no-confidence vote within parliament, but doing this precipitates a general dissolution of parliament. Those choices are aimed at lessening the possibility of gridlock between an unpopular president and a hostile parliament, diminishing the likelihood of mid-term removal of the head of state and giving the head of government a direct popular mandate. As a result, Kiribati has experienced much less political instability than neighbours like Tuvalu and Nauru. 
In the Pacific parliamentary systems, government formation can entail a delicate balancing act. In Solomon Islands, forming a cabinet has always entailed a careful harmonising of representation from the most populous island of Malaita with that from Guadalcanal and the Western Province. Oddly, this has at times benefited politicians from none of those three provinces, such as three-time prime minister Solomon Mamaloni (from Makira) or 2001-06 prime minister Sir Allen Kemakeza (from tiny Savo Island), who could appear to stand above the fray. In Papua New Guinea, it is inconceivable that a cabinet should exclude representatives from the highlands, or Papua, or the Islands. Even Fiji, which in many respects departs from Melanesian political norms owing to its bipolar indigene-Indian cleavage, cautious inclusion of powerful regions becomes politically astute. When Laisenia Qarase sought to forge a power-sharing government with the Fiji Labour Party in May 2006, he was careful to secure his indigenous Fijian base by drawing in paramount chiefs from the Kubuna, Burebasaga, and Tovata confederacies. The neglect of the Tonganinfluenced Lau Islands, already suffering from a fading of the former glory associated with the deceased Ratu Mara's years as prime minister and then president, proved to be that government's Achilles' heel. The revenge of Mara's descendants, or rather the husbands of his daughters, was to become an important aspect of the coup of December $2006 .{ }^{3}$

Romantics often criticise the colonial imposition of 'Westminster' and see this as having disturbed traditional styles of political organisation, which were, it is claimed, characterised by consensus and the 'Pacific way'. ${ }^{4}$ Yet the cleavages that prevail across the Pacific between government and opposition are not mere reflections of inherited institutions. In the small close-knit micro-states, hostility between the government faction and the opposition leadership can on occasions become far more bitter than in the industrialised mass democracies (even though alliances can also, in other circumstances, become fluid and personality-based, and many opposition leaders will, at some point, have served as ministers together in cabinet with those who are now adversaries). Opposition leaders may

3 Ratu Epeli Ganilau was not reappointed as a government nominee to the Great Council of Chiefs in 2004, consequently also losing his position as chair. Ratu Epeli Nailatikau lost his position as speaker after the May 2006 election and was to become ambassador to Malaysia until the 2006 coup intervened. Both men joined the post-2006 coup interim cabinet.

4 A term coined by Fiji's Ratu Sir Kamisese Mara (although it has other claimants) and used to convey a familiar set of contrasts, such as relaxed timekeeping, a preference for leisure over work and consensus over confrontation, felt to distinguish the Pacific from industrialised societies. Similar ideas are found in the Caribbean and Indian Ocean islands. 
find themselves out of government for consecutive parliamentary terms, rendering them vulnerable in their home constituencies. Government victories are carried beyond the floor of the parliamentary chamber, affecting, for example, opposition leaders' private business interests or the promotion prospects of those in their kin groups. When a chance presents itself to dislodge such governments (either through a no-confidence vote or a prime ministerial election), opposition leaders can become desperate and willing to make deals they would otherwise prefer not to make with wavering opportunists. That sharp rivalry amongst Pacific leaders is not, as often imagined, a mere reflection of colonially inherited institutions and can be seen by the regular legal contestation of imposed limits on prime ministerial power (for example, Billy Hilly, Solomon Islands, 1993; Saufatu Sopoanga, Tuvalu, 2002; and Serge Vohor, Vanuatu, 2004, to name but a few).

Absence of major ideological cleavages or political parties with a substantial extra-parliamentary membership can give Pacific parliamentarians considerable freedom for manoeuvre. Occupying a ministerial portfolio not only provides a salary and status that is often impossible for a local to equal in the private sector, it also provides access to state funds and state leverage over foreign-controlled resource-extractive industries. Particularly in Melanesia, MPs have been known to engage in spectacular changes in affinity as they cross the floor to join government, often justifying this by claiming-probably accurately-that they were not elected to government in order to remain on the opposition benches. Many outside cabinet in PNG have preferred to sit on the 'middle benches', poised between government and opposition, so as to be open to offers of ministerial portfolios but equally accessible to being courted by opposition schemers planning assembly of a new government. Regular no-confidence votes in Solomon Islands are popularly believed to be money-making schemes: even if they do not succeed, the MPs all round earn large sums of cash as recipients of rival factions' bids for political support. After Vanuatu's 2008 prime ministerial election, two MPs were inadvertently heard live on national radio talking about the amounts of cash that had exchanged hands, unaware that the microphone was still turned on (Van Trease 2009).

Pacific parliamentarians, although not constrained by powerful party machines, may nevertheless be pressured by local constituents, wantoks or urban networks. The threat of electoral annihilation haunts Western Melanesian incumbents, who generally experience turnover rates well 
above 50 per cent. Politicians in Kiribati are intensely sensitive to home island opinion: while debate on government tabled legislation commands slender interest, question time (when MPs can be heard live on national radio interrogating ministers about matters of local significance) attracts intense interest. Popular engagement in parliamentary processes may be weak, but public interest is strong. When the Marshall Islands Nitijela is in session, most shared taxis running down Majuro's main street will be tuned into the debates. During the 1998-99 struggles between the Kessai Note's UDP and former president Imata Kabua, the public gallery of the Nitijela was packed with onlookers. Jousts between government and opposition leaders in Samoa can likewise grip public attention. Voter turnout is far higher in the Pacific Islands than in North America or Western Europe, and would be higher still if duplicate or deceased voter registrations were deleted from the rolls. Popular engagement with politics is greater than often recognised in the Pacific Islands, even if popular participation in decision-making (e.g. through select committees) is weak and accountability mechanisms work only through the crude three to five yearly ditching of incumbents at each general election.

\section{Decolonisation}

Close integration of territories with metropolitan powers is a legacy of the colonial experience. Hawai' $i$ became the 50th Pacific state in 1959, while other American Pacific territories-Guam, American Samoa and the Commonwealth of the Northern Marianas-are described by the US Supreme Court as having become 'appurtenant to but not a part of the United States' (Underwood 2006:7). Rapa Nui was annexed in 1888 but only legally absorbed into Chile's Valparaiso Province in 1966. Residence on the island by Chileans is still restricted, as is acquisition of property by those not of Rapa Nui descent. By contrast, after West Papua was absorbed into Indonesia with United Nations approval after the Act of Free Choice in 1969, a mixture of spontaneous and sponsored transmigration brought in three-quarters of a million people, mainly from the islands of Java and Sulawesi. Integration with a powerful neighbour tends to open the floodgates to settlement, as on Saipan (Commonwealth of the Northern Marianas) where the majority were non-indigenes in 2000, mostly from the Philippines or China. 
New Caledonia, French Polynesia, and Wallis and Futuna are in law part of the French nation state; all participate in elections for the national assembly and the presidency. The CFP franc, the currency in all three territories, is pegged to the euro. In 1958, French president General Charles de Gaulle insisted on the doctrine of the 'one and indivisible republic', and forced voters in French Polynesia to choose between colonial integration or abrupt secession. Sixty-four per cent voted in favour of staying with France. The pro-independence movement was defeated, and after disturbances in Papeete, its leader, Pouvanaa a Oopa, was imprisoned (Henningham 1992:123-26). The peoples of the French Pacific remain confronted with those stark options, although in modified forms: since 2003 they may opt to become 'territorial collectivities', with considerable autonomy. French Polynesia went a step further by adopting its own autonomy statute. New Caledonia is unique: as a result of the 1998 Noumea Accord, the territory has special legislative powers and a schedule for phased expansion of domestic political control ahead of a referendum on independence between 2014 and 2019. To agree to that accord entailed such a rupture with the doctrine of indivisibility of the Republic that France had to hold a nationwide referendum, the result of which earned New Caledonia a special provision in the constitution (Maclellan 2005:397).

Of the 16 territories in the world that remain on the United Nations list of non-decolonised territories, the Pacific accounts for five: American Samoa, Guam, New Caledonia, Pitcairn Island and Tokelau. Neither of Tokelau's two referenda (2006 and 2007) on whether to become selfgoverning achieved the required two-thirds majority, and Pitcairn Island's links with Britain have, if anything, been reinforced by adjudication of child abuses cases by the British Privy Council. American military build-up on Guam in the new millennium makes independence less likely, despite longstanding Chamorro disquiet about existing arrangements. Inclusion on, or exclusion from, the UN list can prove highly controversial, with behind-the-scenes manoeuvring at the UN headquarters in New York or Geneva being used to exert leverage towards independence back home. The incentives are clear. In 2008, UN Secretary General Ban Ki-moon urged the world 'to complete the decolonisation process in every one of the remaining 16 Non-Self-Governing Territories'. ${ }^{5}$ Pro-independence leader 
Oscar Temaru, after his initial election as French Polynesia's president in 2004, sought to get his country onto the UN list following the precedent set by New Caledonia in the wake of the 1980s Kanak uprising.

Samoa was the first of the Pacific Island states to secure independence in 1962, and the unique constitutional arrangements chosen at that time (discussed later) have probably contributed to that country's postcolonial stability. Tonga formally became independent in 1970, but here the colonial hand was, for the most part, light. Financial irregularities under King George Tupou II (1893-1918) led the British colonists to demand closer control (Fusitu'a and Rutherford 1977:180). Britain became preoccupied with Europe during the 1914-18 war, and on its heels the Great Depression enabled Tupou II's more capable successor Queen Salote to preserve Tonga's political autonomy. Fijis independence was inevitably problematic because of the need to reconcile the competing aspirations of the majority Fiji Indian and minority indigenous Fijian leaders (Norton 2004). Ethnic Fijian claims that since the country had been ceded to Queen Victoria by their chiefs in 1874, it should now be returned to those indigenous chiefs were to become a rallying cry of the ethno-nationalists who overthrew elected governments in 1987 and 2000. Fiji Indian claims that the communally based electoral system left as a compromise by the British at independence perpetuated racebased voting were to become a prominent theme of the military-backed interim government that emerged in the wake of Fiji's third coup in December 2006.

Constitutional choices made at independence also had enduring implications elsewhere in the region, in contrast to Africa where initial legal frameworks bequeathed by colonial powers were often torn up and new arrangements adopted (Chazan et al. 1992). Depth of consultation made a difference to the political authority of whatever structures were chosen. Papua New Guinea (1975) and Kiribati (1979) used constitutional conventions for deliberation, which left recommendations that had lasting political legitimacy (Macdonald 1982). By contrast, although there was more local consultation than is often appreciated in Solomon Islands, the 1978 Independence Order dealt with issues of citizenship in ways that pleased the British Colonial Office and swelled the size of the golden handshake, but provided no durable answer to what was to become a perennial issue in Solomon Islands politics: how to balance the powers of 
the central government against those of the separate islands. ${ }^{6}$ The western breakaway movement that emerged in 1978 was echoed by demands for devolution during a constitutional review a decade later, and then again in the wake of the June 2000 coup when many provinces threatened to secede from the nation (Premdas et al. 1984; Mamaloni 1988; Fraenkel 2004:182). In Vanuatu, the Santo rebellion in 1980 was the most severe of the secessionist crises accompanying independence anywhere in the Pacific region; Jimmy Stevens' Vemerana Provisional Government on Santo threatened to break up the emerging state, until the rebellion was halted by the deployment of British, French and Papua New Guinean troops. The only actual case of secession in Oceania was exceptionally peaceful: in 1976, the British Gilbert and Ellice Islands decided to go their separate ways and a few years later became independent as Kiribati (1979) and Tuvalu (1978). ${ }^{7}$ Bougainville's decade-long conflict first with Papua New Guinea and then internally is the most severe of the modernday secessionist disputes. Its peace settlement, like that of the New Caledonian crisis of the 1980s, included a central provision that delayed the decision on independence for at least a decade. ${ }^{8}$

In between the extremes of independence and incorporation, the Pacific Islands are host to a range of hybrid political arrangements between island territories and former colonial rulers. New Zealand experimented with Compacts of Free Association with Niue and the Cook Islands. Palau, the Federated States of Micronesia and the Republic of the Marshall Islands entered Compacts of Free Association with the US that gave them considerable autonomy (allowing them, unlike the Cook Islands and Niue, to join the United Nations), but left the US with 'strategic denial' rights, enabling the exclusion of other rival superpowers from establishing military bases in that American sphere of influence. As a result of an associated deal, missiles can be fired from Vandenberg air base in California across a 6,760 kilometres arc through the Pacific sky before plunging into the lagoon of Kwajalein Atoll in the Marshall Islands. From there, they can be retrieved and studied by US scientists working

\footnotetext{
6 For background on the constitution-making process, see Ghai 1983.

7 The Congress of Micronesia also broke up into Commonwealth of the Northern Marianas, Republic of the Marshall Islands, Palau and Federated States of Micronesia, but the former was always a US-controlled Trust Territory, not an independent state.

8 New Caledonia's 1988 Matignon Accord put off the scheduled independence vote for a decade. However, in 1998, parties signed the Noumea Accord, which put the scheduled independence vote back further, to some point between 2014 and 2019. Bougainville's peace agreement provides that there will be a vote on independence at some point between 2015 and 2020 .
} 
at the nearby Ronald Reagan Ballistic Missile Defense Test Site. For this, Kwajalein's chiefs-including former president Imata Kabua-receive substantial rental payments, only a fraction of which trickles down to the Ebeye indigenous settlement adjacent to the American base. Negotiations around a new land use agreement for Kwajalein remain an issue of contention between Kwajalein chiefs and the Majuro-based Marshallese government. Washington pragmatically extended its 17 December 2008 deadline for achieving agreement over Kwajalein for a further five years.

For the Marshall Islands and the Federated States of Micronesia, the 1986 Compacts of Free Association expired in 2001. They were extended two years before being renewed for a further 20-year period in 2003, although now with greater scrutiny by the US Department of the Interior. Palau commenced its 15-year compact later than its neighbours in 1994, and so the arrangement expired only in 2009. US secretary of state Hillary Clinton agreed to a one-year extension, and 'compact review' talks commenced in May 2009. Renewed compacts provide the US-associated states with sizeable additions to government revenue-US $\$ 3.2$ billion over the 20 years for the Federated States of Micronesia and the Marshall Islands. They also give access to costly federal programs, for example in health, education and the US mainland postal service.

Atomic rents kept French Polynesia prosperous for many years. Between 1966 and 1975, 41 atmospheric tests were conducted on the remote atolls of Mururoa and Fangataufa, followed by 137 underground tests ending in 1996, when France signed the Comprehensive Nuclear Test Ban Treaty. French aid then declined, but it still accounts for 35 per cent of the French Polynesian GDP. Due to French finance, New Caledonia and French Polynesia easily have the highest income per capita in the Pacific. For the American nuclear-affected islands, independence comes at a price. The Marshall Islands earned global notoriety because of the Bravo nuclear test on Bikini Atoll in 1954. In total, 67 tests were carried out on Bikini and neighbouring Enewetak between 1946 and 1958, the effects of which spread eastwards to Rongelap and Utrik. Washington insists that the US\$250 million paid to the Marshallese Nuclear Claims Tribunal under the first compact, and the similar amount paid for federal programs to affected victims, was 'full and final' compensation. The Marshallese government disagrees. MPs representing the nuclear-affected islands have at times made common cause with Kwajalein's chiefs to urge a more belligerent negotiating stance over the new compact and the land use agreement for the Ronald Reagan Ballistic Missile Defense Test Site. 
The economic advantages of close integration with a wealthy metropolitan power are everywhere apparent; the independent states are, on average, poorer than those which have been incorporated by powerful neighbours around the Pacific Rim or those that have retained close ties with former colonial powers (Bertram 1999:114). For many in the French territories, 'free association' arrangements such as those that connect Pacific states to America and New Zealand would be preferable to the controls from Paris, but the conventional French government position, echoing the Gaullist doctrine of 1958, is to insist that postcolonial linkages can only be decided after the territory settles upon independence. Financial incentives thus act as strong deterrents to loosening ties, even if such marked internal inequalities exist that indigenous groups still back political parties that push for independence.

\section{Political Parties and Integrity Legislation}

Nowhere in the Pacific Islands have the popularly based political parties that are so central to conventional western political thinking emerged. Nowhere do left-right ideological cleavages shape the divide between government and opposition. The only Pacific Island territories with fairly robust political parties are Fiji and New Caledonia, although Vanuatu and French Polynesia have some history of political party organisation. ${ }^{9}$ Ever since independence in Fiji, there has been one party that appeals to the vast majority of ethnic Fijians ${ }^{10}$ and another that represents the Fiji Indians. ${ }^{11}$ The Fijian party has stood little chance in the Indiandominated constituencies and vice versa. In 1997, when Fiji abandoned the first-past-the-post system in favour of the AV system, politicians were persuaded that adopting this modified majoritarian system would be most likely to encourage multi-ethnic government. That proved false. Over the three elections under $\mathrm{AV}$, the party system polarised, so that by the third election under the system in 2006 one party claimed 80 per cent of the ethnic Fijian vote while the other had over 80 per cent of the Indian vote. Despondency as a result of the failure of the AV system to generate

9 For a survey of political parties across the region, see Fraenkel 2006 a.

10 From the 1966 election until the 1987 polls, the Alliance Party, in 1992 and 1994 the Soqosoqo Vakavulewa ni Taukei (SVT) and from the 2001 polls Laisenia Qarase's Soqosoqo Duavata ni Lewenivanua. The exception was the 1999 elections, when the SVT managed only 38 per cent of the Fijian vote, with the remainder split among four other parties.

11 First the National Federation Party and then the Fiji Labour Party. 
anticipated pro-moderation outcomes helps to explain why former centrist politicians and associated civil society activists sympathised with the military coup of December 2006, even if their choice to do so only legitimised Bainimarama's power grab.

In New Caledonia, issue-based political polarisation has also proved sharp, but not on the ethnic pattern of Fiji. Rivalry in the 1980s between the Front de Libération Nationale Kanak et Socialiste (FLNKS) and the French loyalist Rassemblement pour la Calédonie dans la Republique (RPCR) was intense, but ethnicity was not coterminous with political allegiance. Some indigenous Kanaks backed the RPCR, while the proindependence parties always obtained at least some support outside their core Melanesian voter base. The Noumea Accord process in New Caledonia may also have served to erode the bipolar divide, in the sense that parties on both sides have fractured politically. Institutional incentives took the heat off the bipolar conflict and permitted the political emergence of alternative currents of opinion. The territory had long used a closed list proportional representation system, but in the 1998 Noumea Accord supplemented that proportionality in the formation of cabinet through mandatory power-sharing rules. The 1998 deal also devolved power to the provincial assemblies. The contrast between the experience of Fiji and New Caledonia illustrates the perils of using majoritarian systems in bipolar societies with race-based voting.

Few Pacific states have witnessed a strengthening of political party-style organisation. In the Marshall Islands, Kessai Note's UDP administration was elected in 1999 on a 'good governance', accountability and transparency platform ousting Imata Kabua's government. The UDP government survived the 2003 election, but by 2007 was confronted by a rival party that was backed by Imata Kabua and other leading chiefly families in the Ralik chain, the Aelon Kein Ad (AKA). The AKA struck a deal with Nitijela speaker and Ratak chief Litokwa Tomeing, and won the 2007 election. Despite the appearance of an 'evolution' towards political partystyle organisation, allegiances remain fluid in the Marshall Islands. The triumph of the 'visionaries' against the 'old guard' in Nauru in 2004 was not accompanied by development of political parties; the reformist's access to political power always depended on courting wavering opportunists with offers of the presidency. In the smaller Pacific states, a hardening of the opposition often entails the formation of a political party, but, if 
successful in obtaining office, the new government will usually prefer to decry political party-style organisation and claim instead to be ruling in the general interest.

Towards the western Pacific, the absence of robust political parties has become a major issue, leading in some countries to ambitious legislation aimed at encouraging the construction of party-based systems. Papua New Guinea's 2001-02 Organic Law on Political Parties and Candidates aimed to fast-track the development of strong parties by requiring those who back a prime minister after a general election to stick with that choice in any votes of confidence, budgetary votes and votes on constitutional amendments. In an effort to avoid the horse-trading that follows each general election, the party with the largest share of votes is to be given the first opportunity to form a government.

That legislation is widely believed to have ushered in a period of greater stability in PNG; Sir Michael Somare's National Alliance government survived a full 2002-07 term in office, the first government since independence to have achieved this. Somare also succeeded in getting re-elected for a further term after the general election in 2007, and survived beyond the 18-month grace period that ended in February 2009. Yet there are doubts about this simplistic assessment of the stabilising merits of OLIPPAC. While the prime minister remained Somare, deputy prime ministers changed repeatedly over 2002-07, and ministers were regularly reshuffled. Contrary to the rules against floor-crossing, $11 \mathrm{MPs}$ switched sides from government to opposition during the 2002-07 parliament, but none lost their seats as the law said they should do. The Ombudsman - who was in law empowered to act in such cases, if necessary to recommend a forfeit of seats-wisely preferred not to do so. The law proved a toothless tiger, even if in practice floor-crossing did diminish due to the perception of the threat of dismissal. Opposition inside parliament became subdued not so much because of OLIPPAC but because of the presence of a partisan speaker who closed down hostile debate and ruled out of order questions that might embarrass the government. In July 2010, PNG's Supreme Court ruled that key elements of the OLIPPAC violated the freedom of movement provisions in the constitution. ${ }^{12}$

12 Special Reference by Fly River Provincial Executive Council; Re Organic Law on Integrity of Political Parties and Candidates, Supreme Court of Papua New Guinea, 7 July 2010. 
Despite this, the myth of OLIPPAC-engineered stability obtained considerable currency, for there could be little doubt that the political order was more stable than during the chaotic turn-of-the-millennium years (Standish 2000). The more plausible explanation was better handling of the country's second resources boom (Baton et al 2009), and the availability of a good deal more money to grease the political wheels. Other Melanesian countries have been inspired by the PNG experiment, hoping also to discipline their allegedly feckless and unruly backbenchers. Serge Vohor's short-lived 2004 government in Vanuatu wanted to introduce PNG-like 'grace periods', but the court ruled the attempt unconstitutional, and Vohor's government fell to a no-confidence challenge. In Solomon Islands, the post-2007 Sikua-led government was assisted by Australian think tanks in deliberations aimed at adopting legislation inspired by OLIPPAC in PNG (Haywood-Jones 2008). However, several ministers in Dr Sikua's cabinet conspired against the proposed constitutional amendment, which failed to obtain the required two-thirds majority. Those ministers were sacked by Dr Sikua for this act of rebellion, but they re-emerged, holding key portfolios, in the government led by new prime minister Danny Philip after the August 2010 election.

In PNG, Solomon Islands, and Vanuatu, bills and laws have been ostensibly aimed at beefing up political parties, but in practice at strengthening governments and weakening the opposition. Grace periods during which governments cannot be voted out of office tend to be much more popular than financing a costly political party registration apparatus. Although popular concern centres on the horse-trading prior to prime ministerial elections, the rule giving the largest party the first crack at forming a government-by making this a one shot game-generates even greater potential for corruption and instability than the previous arrangements. The risk with 'grace periods', and other forms of restriction on 'no-confidence' motions, is that they allow a deeply unpopular government to retain office, and/or that they require the law courts to intervene to control the minutiae of parliamentary conduct. 


\section{Women's Representation}

Of the nine countries worldwide that have zero women members of parliament, Oceania accounts for five (Solomon Islands, Federated States of Micronesia, Nauru, Palau and Tuvalu). ${ }^{13}$ Papua New Guinea and the Marshall Islands have only a single female MP. Fiji had eight until Bainimarama dissolved parliament in December 2006. Samoa and Niue have four; Guam, Cook Islands and Kiribati have three; and Vanuatu two women MPs. Male dominance of the political stage occurs not only in the national parliaments, but also in local-level assemblies. Traditional male preponderance in the political sphere, and the conservatism of island societies, are the most frequently heard explanations for inequality in political representation. Yet change is in the air, at least in some parts of the Pacific. In western Melanesia, a growing number of women are now contesting elections. By contrast, in some of the smaller and more remote islands, few women contest and those that do are subjected to extraordinary pressures. In some Pacific Island polities, female leaders prefer to keep out of the male-dominated political world, and to concentrate instead on influencing decisions behind-the-scenes or through civil society activism (McCloud 2002). Increasingly aggressive electoral contests have also diminished women's chances on the campaign trail: in the PNG highlands, for example, candidates need access to large sums of cash to win, and they need large numbers of male campaign backers in order to sustain control over the polling booths and coordinate the process of 'assisted voting' (i.e. the completion of ballot papers en masse by sympathisers).

Temporary special measures have been used to increase the number of women in parliament in the French territories and on Bougainville. The French law on parity has given New Caledonia and French Polynesia close to 50 per cent female members of territorial assemblies. That law has not yielded similar results in the third largest French territory, Wallis and Futuna, where constituencies are smaller and where numerous parties enter the contest. Although the parity law requires parties to lodge lists that alternate men and women, since most 'parties' in Wallis and Futuna obtain only a single member, the law does not have the intended effect. Adopting parity laws would have similar results in the other party-less

13 Data from Inter-Parliamentary Union (IPU) website, www.ipu.org/wmn-e/classif.htm. The other states with zero women members are Saudi Arabia, Oman, Qatar and Belize. The IPU dataset records only states that are members of the United Nations, not territories like American Samoa and Commonwealth of the Northern Marianas that also have zero female MPs. 
Pacific microstates (Fraenkel 2006b). Where political parties are absent or weak, reserved seats are the only legal measure likely to increase the number of women in parliament. The autonomous region of Bougainville is the sole entity in Oceania to have adopted reserved seats for women. Three of Bougainville's 41 seats are reserved for women. In both Papua New Guinea and Solomon Islands, increasing numbers of female candidates are contesting elections, and in both countries there are pressures for reserved seats to increase the number of women in parliament.

Although women are poorly represented in Pacific parliaments, they tend to be better represented at the top levels of the civil service, where appointments are more likely to be on merit. For example, as of late 2009, Kiribati women accounted for only three MPs in its 46 member parliament ( 6.5 per cent), but seven of the 15 top positions in the I-Kiribati civil service (46 per cent). In Solomon Islands, Nauru, and Samoa, the percentage of women in top positions in the ministries is also markedly higher than the share in parliament. The secretaries in the I-Kiribati ministries are, probably uniquely in the Pacific, paid considerably more than parliamentarians. Much of the consultation around new legislation occurs through the ministries, prior to agreement in cabinet and before bills are tabled in parliament. In Kiribati, as in many other Pacific countries, highly qualified women prefer to take positions formulating and implementing policy, rather than going on the election campaign trail or joining male-dominated legislative assemblies. The Kiribati parliament is an assembly open to those over the civil service retirement age of 55, and it is a place where MPs focus largely on constituency matters rather than law-making.

\section{Power-sharing Accords}

The Pacific has an interesting but little internationally known experience with mandatory power-sharing accords. Nowhere in the world has witnessed such extensive litigation about mandatory power-sharing rules as Fiji. In the 1997 Fiji constitution, a power-sharing provision required that all parties with 10 per cent or more of seats be proportionally represented in cabinet. The provision was modelled on that in South Africa during the transition from apartheid, and similar rules were adopted in Northern Ireland as part of the Good Friday Agreement in 1998. When Mahendra Chaudhry formed his Labour-led People's 
Coalition cabinet after the 1999 Fiji election, he proved able to exclude the largest Fijian party, Rabuka's Soqosoqo Vakavulewa ni Taukei, on the grounds that its leaders imposed conditions on cabinet entry that amounted to a decline of the invitation. When Chaudhry's arch-adversary Laisenia Qarase tried to follow that legal precedent after the elections of 2001, the Court of Appeal rejected his efforts as contrary to the 1997 constitution. Qarase appealed and the cases dragged on until 2004 before the Supreme Court left Qarase's Soqosoqo Duavata ni Lewenivanua party with no option other than to invite Chaudhry's Fiji Labour Party (FLP) into cabinet. Qarase reluctantly complied by offering the FLP a series of token minor portfolios in a cabinet so swollen that his former ministers also retained their portfolios. It was, unsurprisingly after so much legal action, a compromise with the letter but not the spirit of the law. The FLP condemned the expansion in cabinet size as a costly imposition on Fiji's people and criticised the portfolios as trivial. Since a fresh election was anyway looming on the horizon, Chaudhry chose instead to occupy the opposition benches.

After the 2006 election, Qarase complied more wholeheartedly with Fiji's multi-party cabinet rules, drawing nine senior FLP parliamentarians into cabinet, and giving them major portfolios. It proved an enormously popular decision, but Fiji's political leaders again failed to make the arrangements work. Chaudhry stayed out of cabinet, and eventually expelled two of the participating FLP ministers. The short-lived 2006 power-sharing cabinet was the first government since independence to have brought members from the country's two largest parties-one representing the Fijians and the other the Fiji Indians-into cabinet (Green 2009). It lasted just seven months before being overthrown by military commander Frank Bainimarama.

In New Caledonia, by contrast, power-sharing provisions agreed as part of the 1998 Noumea Accord worked more smoothly, even if they left the pro-independence parties in a minority. In all post-accord cabinets, the loyalist parties dominated, based on their ascendancy in the more densely populated Southern Province and their ability to gain a minority of seats in the majority Kanak Northern Province. During the initial post-Noumea Accord government, the pro-independence groups regularly took legal action regarding the composition of government. However, after the 2001 assumption of the presidency by the RPCR's Pierre Frogier, Kanak activist Déwé Gorodé was selected as vice president, thus meeting one of the major FLNKS demands. The 2004 election saw 
a fracturing amongst the loyalist parties, with the emergence of Avenir Ensemble, a trend continued at the 2009 election, with further splits this time affecting Avenir Ensemble. Pro-independence parties have also been prone to schisms. The other Noumea Accord provisions of devolution of powers from Paris to Noumea, and a re-balancing of income towards the predominantly Kanak Northern and Loyalty Islands Provinces have helped to encourage the emergence of new alignments also among the Kanak parties.

New Caledonia's arrangements had a more solid foundation than those in Fiji. Provisions for the proportional distribution of ministerial appointments fitted better with New Caledonia's list PR electoral system than with Fiji's majoritarian AV system. Fiji's Westminster-based 1997 constitution was not sufficiently redrafted after the belated inclusion of the 10 per cent rule, and drafters did not fully consider the likely difficulties of a prime minister needing to form a coalition government to 'command a majority' on the floor of the house while at the same time being required to form a power-sharing cabinet that includes all the qualifying parties. Whereas Fiji's power-sharing rule generated bipolar incentives for each ethnic group to avoid splits that might entail parties falling below the 10 per cent threshold required for cabinet participation, New Caledonia's rules allowed smaller parties to combine with larger parties to boost cabinet entitlements. New Caledonia's arrangements were considerably assisted by French aid subventions, and by a growing flexibility emanating from Paris as regards which institutions might prove acceptable. Fiji had to tackle its problems alone, with little in the way of helpful advice from supranational institutions or powerful neighbours.

\section{Conclusion: Postcolonial Trends}

Does the closing of the post-independence honeymoon era represent a shift to permanent volatility, or merely a hiatus before some new leadership consolidation? Efforts by elites to stabilise and regiment the political order have been most ambitious in Papua New Guinea, with OLIPPAC and 'grace periods', but, as we have seen, similar devices are being experimented with in Solomon Islands and have been tried, unsuccessfully, in Vanuatu. Samoa's HRPP is the only political party across the region that has remained in office for close to a quarter of a century, consolidating its control by expanding cabinet size, increasing 
the parliamentary term to five years, outlawing party switching and creating new sub-ministerial positions for pro-government backbenchers. Solomon Islands and Tuvalu have sought to increase cabinet size, so as to render the executive more resilient to parliamentary challenge. Whether those efforts prove successful, whether they prove harbingers of emergence of more authoritarian political elites, or whether the post-independence era's highly contested and fluid styles of politics reassert their influence remains to be seen.

\section{References}

Bertram, G. 1999. The MIRAB Model Twelve Years On. The Contemporary Pacific 11(1):105-38.

Chazan, N., R. Mortimer, J. Ravenhill and D. Rothchild 1992. Politics and Society in Contemporary West Africa, 2nd ed. Boulder: Lynne Rienner. doi.org/ 10.1007/978-1-349-12976-8

Fraenkel, J. 2004. The Manipulation of Custom: From Uprising to Intervention in the Solomon Islands. Wellington: Victoria University Press.

Fraenkel, J. 2006a. The Political Consequences of Pacific Island Electoral Laws. In R. Rich, L. Hambly and M. Morgan (eds), Political Parties in the Pacific Islands. Canberra: Pandanus.

Fraenkel, J. 2006b. The Impact of Electoral Systems on Women's Representation in Pacific Parliaments. In A Woman's Place is in the House-the House of Parliament: Research to Advance Women's Political Representation in Forum Island Countries. Suva: Pacific Islands Forum Secretariat.

Fraenkel, J. and B. Grofman 2006. Does the Alternative Vote Foster Moderation in Ethnically Divided Societies? The Case of Fiji. Comparative Political Studies 39(5):623-51. doi.org/10.1177/0010414005285032

Frazer, I. 1997. The Struggle for Control of Solomon Islands Forests. The Contemporary Pacific 9(1):39-72.

Fusitu'a, E. and N. Rutherford 1977. George Tupou II and the British Protectorate. In N. Rutherford (ed.), Friendly Islands: A History of Tonga. Melbourne: Oxford University Press.

Ghai, Y. 1983. The Making of the Independence Constitution. In P. Larmour (ed.), Solomon Islands Politics. Suva: University of the South Pacific. 
Green, M. 2009. Fiji's Short-lived Experiment in Executive Power-Sharing, MayDecember 2006. State, Society and Governance in Melanesia Discussion Paper 2009/2. Canberra: The Australian National University.

Hayward-Jones, J. 2008. Engineering Political Stability in Solomon Islands: Outcomes Report. Sydney: Lowy Institute.

Henningham, S. 1992. France and the South Pacific; A Contemporary History. Sydney: Allen and Unwin.

Macdonald, B. 1982. Cinderellas of Empire; Towards a History of Kiribati and Tuvalu. Canberra: Australian National University Press.

Maclellan, N. 2005. From Eloi to Europe: Interactions with the Ballot Box in New Caledonia. Commonwealth \& Comparative Politics 43(3):394-417. doi.org/10.1080/14662040500304890

Mamaloni, S. 1988. 1987 Constitutional Review Committee Report, Vol. 2. Honiara: Government Printer.

May, R. 2008. The 2007 Election in Papua New Guinea, State Society and Governance in Melanesia Briefing Note 7, Canberra: The Australian National University.

McCloud, A. 2002. Where Are the Women in Simbu Politics? Development Bulletin 59:43-46.

Norton, R. 2004. Seldom a Transition with Such Aplomb: From Confrontation to Conciliation on Fiji's Path to Independence. Journal of Pacific History 39(2):147-62. doi.org/10.1080/0022334042000250715

Panapa, P. and J. Fraenkel 2008. The Loneliness of the Pro-Government Backbencher and the Precariousness of Simple Majority Rule in Tuvalu. State, Society and Governance in Melanesia Discussion Paper 2008/2. Canberra: The Australian National University.

Premdas, R., J. Steeves and P. Larmour 1984. The Western Breakaway Movement in Solomon Islands. Pacific Studies 7(2):34-67.

Reilly, B. 2001. The Borda Count in the Real World: The Electoral System in the Republic of Nauru. Macmillan Brown Centre for Pacific Studies Working Paper 8. Christchurch: University of Canterbury.

So'o, A. and J. Fraenkel 2005. The Role of Ballot Chiefs and Political parties in Samoa's Shift to Universal Suffrage. Commonwealth \& Comparative Politics 43(3):333-61. doi.org/10.1080/14662040500304973 
Standish, B. 2000. Papua New Guinea 1999: Crisis of Governance. Australian Parliamentary Library, Research Paper 4. Canberra: Parliamentary Library, Parliament of Australia.

Underwood, R. 2006. Micronesian Political Structures and American Models: Lessons Taught and Lessons Learned. Journal of Pacific Studies 29(1):4-24.

Van Trease, H. 2005. The Operation of the Single Non-Transferable Vote System. Commonwealth \& Comparative Politics 43(3):296-332. doi.org/10.1080/ 14662040500304833

Van Trease, H. 2009. Vanuatu's 2008 Election-Difficulties of Government Formation in a Fractionalized Setting. State, Society and Governance in Melanesia Briefing Note 2009/1. Canberra: The Australian National University. 
This text is taken from Understanding Oceania: Celebrating the University of the South Pacific and its collaboration with The Australian National University, edited by Stewart Firth and Vijay Naidu, published 2019 by ANU Press, The Australian National University, Canberra, Australia.

doi.org/10.22459/UO.2019.07 